\title{
IMPLEMENTASI KETERAMPILAN BAHASA SISWA DI MI DARUSSALAM 01 PUCANGAN KARTASURA SUKOHARJO TAHUN PELAJARAN 2019/2020
}

\author{
Rizky Nur Aini \\ MI Al Husna Tangen Sragen \\ E-mail: rizkynuraini578@gmail.com
}

\begin{abstract}
This study aims to analyze the implementation of class $V$ Indonesian language skills at MI Darussalam 01 Pucangan Kartasura Sukoharjo. This research uses descriptive qualitative research, which was conducted in the even semester of the 2019/2020 school year. The subjects in this study were thematic subject teachers as well as class $V$ homeroom teachers, the principal, and some of the fifth grade students. The data collection methods used interviews, observation, and documentation. The data validity technique used source triangulation and method triangulation techniques. Data analysis used an interactive analysis model, namely the steps of data collection, data reduction, data presentation, and drawing conclusions. Based on data analysis from the implementation of students' language skills, it can be concluded that the methods used in training language skills use a variety of learning methods such as the STAD (Student Team Achievement Divisions) method, CIRC (Cooperative Integrated Reading and Composition), TAI (Team Assisted Individualization), and storytelling.
\end{abstract}

Keywords: Language Skills; Primary school student

Abstrak Penelitian ini bertujuan untuk menganalisis implementasi keterampilan bahasa Indonesia kelas V di MI Darussalam 01 Pucangan Kartasura Sukoharjo. Penelitian ini menggunakan jenis penelitian kualitatif deskriptif, yang dilaksanakan pada semester genap tahun ajaran 2019/2020. Subyek dalam penelitian ini guru mata pelajaran tematik sekaligus wali kelas V, kepala sekolah, dan sebagian siswa kelas $\mathrm{V}$. Metode pengumpulan data menggunakan wawancara, observasi, dan dokumentasi. Teknik keabsahan data menggunakan teknik triangulasi sumber dan triangulasi metode. Analisis data menggunakan model analisis interaktif yaitu dengan langkahlangkah pengumpulan data, reduksi data, penyajian data, dan mengambil kesimpulan. Berdasarkan analisis data dari implementasi keterampilan bahasa siswa dapat disimpulkan metode yang digunakan dalam melatih keterampilan bahasa menggunakan variasi metode pembelajaran seperti metode STAD (Student Team Achievement Divisions), CIRC (Cooperative Integrated Reading and Composition), TAI (Team Assisted Individualization), dan bercerita.

Kata Kunci: Keterampilan Bahasa; Siswa MI

\section{PENDAHULUAN}

Pendidikan pada dasarnya berasal dari beberapa sumber, tidak hanya berasal dari buku, akan tetapi dapat juga dari pengalaman hasil dari hubungan-hubungan antara individu dengan individu, individu dengan kelompok, maupun hubungan individu dengan lingkungan atau alam sekitar. Pendidikan dapat dibatasi melalui lingkupnya seperti waktu dan ruang, suatu 
proses pendidikan berlangsung sementara dan dipengaruhi tidak hanya diri sendiri melainkan individu lain dan benda-benda di sekitar. Seperti di sekolah, siswa mendapatkan pendidikan dari pendidik bagaimana pendidik itu menyampaikan pembelajaran, bagaimana bersikap, dan segala apa yang pendidik lakukan menjadi suatu pendidikan bagi siswa (Naim, 2009). Pendidik memiliki peran yang penting bagi siswa, karena apa yang pendidik lakukan menjadi ilmu bagi siswa, bagaimana pendidik memberikan pengetahuan, dan bagaimana menggunakan sumbersumber belajar yang tersedia, bagaimana pendidik menyampaikan, dan bagaimana pendidik mampu memahami siswa dalam mendidik. Pendidikan tercapai karena adanya pembelajaran dan pihak-pihak dari perangkat tertentu sebagai perantara, seperti guru, media, metode, dan strategi yang digunakan dalam pembelajaran tersebut (Yahya, 2013).

Pencapaian tujuan dalam pendidikan diperlukan upaya-upaya yang dilakukan dari pihak sekolah. Mulai dari penyedian sarana prasarana, guru yang mahir dalam menerapkan metode dan media pembelajaran, mampu mengelola kelas dengan baik, dan menjalin kemunikasi yang tepat dalam pembelajaran. Menjadi guru yang ideal itu tidak mudah, membentuk generasi yang berhasil dalam pembelajaran seperti mampu mengerti dan faham apa yang diajarkan, mampu menguasai metode, strategi dan perangkat lain yang digunakan. Sehingga dapat mencapai tujuan dari pendidikan, dalam pembelajaran apa yang guru sampaikan dan lakukan merupakan suatu patokan bagi siswa, jadi guru hendaknya berperilaku yang baik dan beradab. Mampu menguasai kelas, mengelola kelas, memahami siswa, dan menguasai pola komunikasi dikelas.

Komunikasi sangat mempengaruhi dalam pembelajaran, dengan melalui komunikasi guru dapat mengetahui apakah siswa mampu menerima atau tidak apakah yang disampaikan guru dapat difahami oleh siswa atau malah sebaliknya (Henry, 1994). Sehingga guru harus mampu mengetahui dan menerapkan bagaimana komunikasi yang jelas, baik, menarik, dan interaktif dapat di fahami oleh siswa sehingga selain berhasil dalam pembelajaran, siswa juga mampu mengalami perkembangan baik keterampilan, komunikasi, berbahasa, dan berperilaku

Menurut Keraf (1997: 3) bahasa memiliki fungsi yang penting dalam kehidupan, terutama untuk berkomunikasi dan menjalin hubungan dengan sesama. Bagaimana seseorang berbahasa, menyampaiakan informasi, dan menangkap informasi berdasarkan bahasa yang digunakan. Bahasa diantaranya memiliki fungsi seperti sebagai alat menyampaikan ekspresi, komunikasi, alat mengendalikan diri, dan menyesuaikan dengan individu lain. Adapun fungsi bahasa secara 
umum menurut Widjono (2007: 15) yaitu: bahasa sebagai sarana komunikasi, bahasa sebagai sarana integrasi dan adaptasi. Oleh karena itu, guru harus mampu menyampaikan informasi pembelajaran kepada siswa dengan bahasa yang komunikatif mampu diterima dan difahami oleh siswa, dan bagi siswa yang memiliki pola komunikasi berbeda, guru juga harus mampu untuk menyesuaikan.

Cara-cara mengekspresikan diri, mengungkapkan pendapat, menuangkan pikiran, dapat untuk mengukur seberapa dalam siswa mampu menyerap pembelajaran yang guru sampaikan. Melalui berbicara, menulis, menyimak, dan membaca keempat kemampuan itu saling berhubungan sehingga guru hendaknya bersikap aktif dan peka untuk mampu menumbuhkan kemampuan tersebut kepada siswa, dengan melalui proses karena memang pembentukan tersebut tidaklah instan.

Perlu waktu dan berbagai cara untuk siswa tertarik dan cenderung mengungkapkan apa yang siswa terima. Semua kebiasaan aktif terbentuk tidak sekedar berasal dari teori melainkan dari sikap dan perilaku guru dalam menyampaikan pembelajaran, semuanya di terima oleh siswa melalui keadaan sengaja maupun tidak disengaja karena pada dasarnya pendidikan sekolah dasar merupakan usia yang optimal dalam penanaman pendidikan dasar. Keadaankeadaan siswa yang mudah berubah suasana hatinya menjadikan siswa kurang mencintai proses, sehingga dalam pembelajaran cenderung mencuri dan mencari kegiatan selain pembelajaran. Menerapkan sikap berani, aktif, memiliki rasa ingin tau, dan tekun adalah sesuatu yang tidak mudah diterapkan. Jika tidak dengan melalui pembiasaan-pembiasaan kecil dalam kehidupan sehari-hari.

Siswa malu menyampaikan pendapat, kurang minat menulis, rendah minat membaca, dan mudah jenuh dalam mendengarkan. Menurut Ismawati \& Umaya (2012: 29) siswa yang karena malu, kurang percaya diri, kurang konsentrasi, kurangnya minat siswa, dan guru yang kurang variatif dalam menggunakan media, dan kurang variatif dalam mengelola pembelajaran, sedangkan faktor penyebab diatas, yang dominan berdasarkan observasi yaitu kurangnya kesdaran siswa akan pentingnya keterampilan bahasa, guru kurang memerankan siswa untuk aktif, terutama dalam membaca, menulis, menyimak, dan berbicara.

Kurangnya minat siswa untuk membaca, siswa yang malu dan tidak percaya diri dalam mengungkapkan pendapat, mudah bosan dalam menyimak, serta siswa yang kurang minat dalam menulis. Disinilah peran guru untuk mampu memerankan aktif kemampuan siswa 
dalam keterampilan bahasa dengan adanya variasi dalam menggunakan metode, dan media dalam pembelajaran dengan menyesuaiakan kedaan setiap siswa yang berbeda. Sehingga penulis tertarik untuk mengetahui keterampilan bahasa indonesia siswa.

\section{METODE PENELITIAN}

Penelitian ini merupakan penelitian kualitatif deskriptif, dimana peneliti menganalisis, mengkaji, dan menggambarkan bagaimana pelaksanaan keterampilan bahasa Indonesia di kelas $\mathrm{V}$ pada pembelajaran tematik. Penelitian jenis ini dapat berkomunikasi langsung dengan subyek dan informan karena untuk mendapatkan informasi dan data-data yang akurat untuk menyusun penelitian. Tempat pengambilan data penelitian dilakukan di MI Darussalam 01 Pucangan Kartasura Sukoharjo. Subyek dalam penelitian ini adalah guru wali kelas V MI Darussalam 01 Pucangan Kartasura Sukoharjo, kepala MI Darussalam 01 Pucangan Karatsura dan siswa kelas V MI Darussalam 01 Pucangan Kartasura. Teknik pengumpulan data yang digunakan melalui wawancara, observasi, dan dokumentasi. Validasi data triangulasi sumber dan triangulasi dengan metode analisis data diawali dengan pengumpulan data, reduksi data, penyajian data dan yang terakhir penarikan kesimpulan.

\section{HASIL DAN PEMBAHASAN}

\section{Implementasi Keterampilan Bahasa Siswa di MI Darussalam 01 Pucangan Kartasura}

Keterampilan bahasa Indonesia penting dimiliki oleh setiap orang. Seperti yang disebutkan dalam teori Ismawati dan Umaya (2012: 48) Keterampilan bahasa Indonesia menjadi dasar bagi seseorang untuk berkomunikasi, berekspresi, menyampaikan informasi dan menangkap informasi dari orang lain atau lingkungan. Setiap pembelajaran menerapkan keterampilan bahasa antara lain seperti membaca, menulis, menyimak, dan berbicara. Tanpa memiliki keterampilan bahasa seseorang mengalami hambatan dalam berkomunikasi. hal ini sesuai dengan pendapat Nafi' ah (2018: 93) bahwa dalam pembelajaran bahasa terdapat beberapa kegiatan dari membaca, mendengarkan, menyimak, melihat atau mengamati sesuatu dalam proses pembelajaran.

Berdasarkan hasil penelitian yang dilakukan oleh peneliti, didapatkan berbagai macam metode pembelajaran yang dilakukan oleh guru dalam pelaksanaan pembelajaran bahasa Indonesia, dapat diinterpretasikan peneliti bahwa dalam pelaksanaan keterampilan bahasa 
Indonesia pada pembelajaran tematik dapat tercapai karena ditemukan metode STAD, diskusi, tanya jawab, dan CIRC pada keterampilan bahasa Indonesia seperti membaca, menyimak, dan berbicara. Hal ini sesuai dengan salah satu peran guru menurut Majid (2014: 183) mampu mengelola kelas dan menciptakan suasana kelas yang menyenangkan bagi siswa dengan menggunakan berbagai metode pembelajaran.dit

a. Menyimak

Menurut Ismawati \& Umaya (2012: 48) menyimak adalah suatu kegiatan memahami dari suatu pesan yang disampaikan dengan cara mendengarkan secara seksama, dan penuh konsentrasi sehingga dapat menerima apa yang disampaikan dengan baik. Keterampilan menyimak kelas V MI Darussalam 01 Pucangan terlihat baik. Terdapat metode bercerita dan diskusi dalam pelaksanaan pembelajaran tematik yang berjalan. Pembelajaran tematik mendorong siswa untuk aktif dan kreatif, namun jika dilakukan tanpa adanya metode yang bervariasi oleh guru, tujuan pembelajaran tidak akan tercapai. Metode diskusi dalam pembelajaran tematik memberikan suasana yang kondusif, dan dengan menyimak dengan baik siswa mampu bertanya dan menjawab. Karena suatu awal diskusi terdapat pengantar materi yang disampaikan oleh wali kelas selaku walikelas V sebagai pengarah jalannya diskusi. Hal ini sesuai dengan pendapat menurut Tarigan (2002: 28) menyimak adalah suatu proses kegiatan mendengarkan lambang-lambang, simbol-simbol lisan dengan seksama, penuh perhatian, pemahaman, memberikan pendapatan, pandangan, serta penilaian untuk memperoleh informasi, menangkap isi yang disampaikan oleh pembicara melalui ujaran, atau bahasa lisan secara langsung maupun tidak langsung.

Materi yang disampaikan wali kelas berjalan dengan baik, siswa manyimak dengan seksama. Wali kelas mencoba memberikan pertanyaan kepada siswa, siswa dapat menjawab dengan baik. Setelah disampaikan pengantar materi, maka dilakukan kegiatan diskusi dengan pembagian kelompok menjadi empat sampai lima kelompok. Setiap kelompok menyampaikan hasil dari diskusi di depan kelas. Siswa yang mendapat bagian maju kedepan kelas untuk menyampaikan hasil diskusi dengan percaya diri, sedangkan kelompok yang lain memperhatikan, karena dengan memperhatikan hasil diskusi dari kelompok lain agar siswa paham, dan mampu memberikan pertanyaan, dan bagi siswa yang aktif memebrikan pertanyaan diberikan tambahan nilai keaktifan oleh wali kelas. Oleh karena itu, siswa semangat dan antusias dalam memberikan pertanyaan secara bergantian. Hal ini sesuai dengan teori Safruddin Nurdin, 
Basyiruddin Usman (2003: 8) guru merupakan seorang yang mampu menjadikan siswanya dapat merencanakan sesuatu yang akan dilakukan, menganalisis sesuatu yang telah dilakukan berdasarkan ilmu-ilmu dan teori-teori yang didapatkan serta mampu menyimpulkan masalah yang dihadapi dengan memberikan solusi-solusi yang bermakna.

Diskusi berjalan dengan baik, meskipun ditengah-tengah proses belajar mengajar siswa terkadang juga mengalami kebosanan, mulai mengalihkan perhatian, dan bergurau dengan teman. Adanya hal tersebut, wali kelas dapat mengambil sikap, dan tindakan. Wali kelas memberikan selingan cerita menarik, yang bertujuan menarik perhatian siswa kembali, mengembalikan kosentrasi, dan kefokusan siswa. Adanya sepenggl cerita dari wali kelas membuat siswa kembali pada pembelajaran diskusi dengan kondusif kembali.

b. Berbicara

Berbicara menjadi keterampilan dasar bahasa Indonesia. Keterampilan berbicara siswa kelas V sudah terbilang cukup pada saat pembelajaran berlangsung. Ketika pembelajaran tematik berlangsung, terdapat metode yang dilaksanakan dalam mengaktifkan keterampilan berbicara siswa. Metode yang terdapat saat itu yaitu STAD. Pembelajaran tematik menerapkan metode STAD dengan melibatkan kegiatan ceramah, diskusi, dan tanya jawab. Hal ini sesuai dengan pendapat Hendriani (2016: 121) Peran Guru yaitu, sebagai berikut: guru sebagai model, guru sebagai perencana (planning), guru sebagai "penemu" kesulitan belajar siswa (diagnostician).

Keterampilan bicara siswa dilatih dalam kegiatan diskusi dengan cara siswa mempresentasikan hasil dari diskusi di depan kelas, setelah selesai presentasi, siswa dalam kelompok yang lain bertanya, dan kelompok siswa presentasi menjawab pertanyaan. Kegiatan tanya jawab dilakukan seputar materi praktikum yang telah dilaksanakan sebelumnya. Kagiatan tanya jawab berjalan dengan baik, siswa aktif dan antusias dalam berdiskusi. Bagi siswa yang aktif, diberikan nilai tambahan oleh wali kelas sebagai nilai keaktifan. Hal ini sesuai dengan pendapat Baverly (2015: 377) Kegiatan-kegiatan yang dapat mempengaruhi perkembangan bahasa anak yaitu meliputi kegiatan yang berpusat pada suatu penyelidikan, penemuan, dan kegiatan yang diarahkan dan direncanakan oleh guru. Melalui kegiatan yang diarahkan dan di rencanakan oleh guru ini, siswa dapat di dorong untuk mengembangkan kemampuan berbahasa untuk belajar, memahami, dan menanyakan

c. Membaca

Keterampilan membaca pada kelas V MI Darussalam 01 Pucangan berjalan dengan baik. 
Pelaksanaan pembelajaran berjalan dengan kondusif dengan adanya metode CIRC, diskusi dan tanya jawab. Adanya metode CIRC sebelum membahas ke dalam diskusi siswa membaca bahan materi terlebih dahulu, karena tanpa dengan membaca siswa tidak akan tahu materi yang akan didiskusikan serta tanpa membaca siswa tidak bisa menjawab pertanyaan yang diajukan oleh wali kelas. Menurut pendapat Eta (2011: 73) Mempelajari keterampilan bahasa seperti membaca, menulis, menyimak, dan berbicara dapat digunakan sebagai bekal individu dalam berkomunikasi baik secara lisan, dan tulisan oleh karena itu keterampilan bahasa pentng untuk dikembangkan. Siswa membaca bacaan dengan kondusif untuk mengetahui serta memahami isi yang terkandung di dalam bacaan. Hal ini sesuai dengan teori Dalman (2013: 8) bahwa membaca mampu menghadirkan makna-makna dari apa yang telah dibaca, mampu mengusai kosa kata, dan mampu mendorong keterampilan-keterampilan berbahasa yang lain.

d. Menulis

Menulis menjadi salah satu keterampilan bahasa yang merupakan keterampilan dasar yang dimiliki oleh setiap orang. Karena menulis merupakan suatu kemampuan yang menjadi salah satu alat untuk komunkasi dengan orag lain. Melalui kemampuan menulis, seseorang mampu berinteraksi dengan orang lain, menyampaikan ekspresi, juga perasaan dari seseorang. Penelitian yang dilakukan peneliti di kelas V MI Darussalam 01 Pucangan Kartasura pada keterampilan menulis siswa sudah lumayan baik.

Kemampuan yang didampingi dengan latihan-latihan menjadikan suatu keterampilan termasuk dalam hal menulis. Secara keseluruhan siswa kelas V sudah baik, minat perlu di diciptakan dalam setiap harinya dengan adanya upaya yang dilakukan guru seperti memberikan variasi dalam menggunakan metode pembelajaran. Seperti mnggunakan metode diskusi, CIRC , dan juga TAI dalam melatih keterampilan menulis siswa kelas V. Sehingga dengan menggunakan metode tersebut, siswa lebih aktif, dan antusias dalam latihan menulis. Siswa yang mengalami keterlambatan menulis juga menjadi aktif dalam berlatih dan berusaha untuk tidak tertinggal pelajaran dengan siswa yang lain

\section{Faktor Pendukung dan Faktor Penghambat Pelaksanaan Keterampilan Bahasa Siswa}

a. Faktor Pendukung; 1) Adanya perencanaan pembelajaran melalui pembuatan Rencana Pelaksanaan Pembelajaran (RPP); 2) Adanya variasi metode pembelajaran; 3) Kepekaan dari guru dalam memahami kemampuan setiap siswa; 4) Lingkungan yang mendukung dalam penggunaan metode pembelajaran. 
b. Faktor Penghambat; 1) Kegiatan diskusi yang dilaksanakan membuat kondisi kelas menjadi ramai; 2) Kurangnya ketersediaan media pembelajaran dari sekolah.

\section{KESIMPULAN}

Berdasarkan hasil penelitian yang telah dilakukan mengenai pelaksanaan keterampilan bahasa Indonesia pada pembelajaran tematik kelas V MI Darussalam 01 Pucangan Kartasura yaitu: 1) Implementasi keterampilan bahasa Indonesia pada pembelajaran tematik kelas $V$ yang dilakukan oleh walikelas $\mathrm{V}$ dan guru pengampu mata pelajaran tematik sudah berjalan dengan baik dan lancar. Hal ini sesuai dengan pendapat yang diungkapkan oleh kepala sekolah bahwa wali kelas dalam melaksanakan pembelajaran dalam mengembangkan keterampilan bahasa Indonesia seperti membaca, menyimak, menulis dan berbicara menggunakan variasi metode. Hal tersebut juga sesuai dengan pendapat yang diungkapkan oleh siswa kelas $\mathrm{V}$ bahwa pembelajaran tematik dengan metode STAD perpaduan antara ceramah, diskusi, tanya jawab. CIRC, TAI dan bercerita mudah difahami dan menyenangkan. Siswa terdorong untuk lebih aktif, tertarik dalam membaca, menyimak, menulis serta berbicara seperti mengungkapkan pendapat di dalam kelas tanpa rasa malu dan takut salah. 2) Implementasi keterampilan bahasa siswa di MI Darusalam 01 Pucangan Kartasura memiliki faktor pendukung seperti, adanya perencanaan pembelajaran melalui pembuatan RPP, adanya variasi metode pembelajaran, kepekaan dari guru dalam memahami setiap siswa, lingkungan yang mendukung dalam penggunaan metode pembelajaran. Faktor penghambat, seperti kegiatan diskusi yang dilaksanakan membuat kondisi kelas menjadi ramai, memerlukan banyak waktu, kurangnya ketersediaan media pembelajaran dari sekolah.

\section{DAFTAR RUJUKAN}

Beverly, O. (2015). Perkembangan bahasa pada anak usia dini. Jakarta: Prenadamedia Group. Dalman. (2013). Keterampilan membaca. Jakarta: Pt Raja Grafindo Persada.

Eta, K. (2011). Teaching the four language skills in primary efl classroom: Some considerations. Jakarta: Sekolah Pelangi Kasih Nasional-Plus.

Hendriani, D. (2016). Pengembangan seni budaya dan keterampilan. Yogyakarta: Ombak Tiga. Ismawati, E., Umaya, F. (2012). Bahasa indonesia untuk penulisan karya ilmiah. Yogyakarta: Ombak Dua.

Ismawati, E., Umaya, F. (2012). Belajar bahasa di kelas awal. Yogyakarta: Ombak. Keraf, G. (1997). Komposisi sebuah pengantar kemahiran bahasa. Jakarta: Nusa Indah. Majid, A. (2014). Pembelajarn tematik terpadu. Bandung: PT Remaja Rosdarya. Nafi' ah, S.A. (2018). Model-model pembelajaran bahasa indonesia: Yogyakarta: Ar-Ruzz Media. 
Naim, N. (2009). Menjadi guru inspiratif. Yogyakarta: Pustaka Pelajar.

Tarigan, H.G. (1994). Menyimak sebagai suatu keterampilan berbahasa. Bandung: Angkasa

Widjono. (2007). Bahasa indonesia mata kuliah pengembangan kepribadian di perguruan tinggi. Jakarta: PT Grasindo.

Yahya, M. (2013). Profesi tenaga kependidikan. Bandung: CV Pustaka Setia. 